\title{
Tipo de cambio real y finanzas públicas subnacionales: efectos de las depreciaciones reales en Argentina
}

Real Exchange Rate and Subnational Public Finance: the Effects of Real Depreciation in Argentina Tipo de câmbio real e finanças públicas subnacionais: efeitos das depreciações reais na Argentina

Julián Mariano Puig Universidad Nacional de la Plata, Buenos Aires, Argentina

E-mail: julianmpuig@gmail.com

\author{
Diego Andrés Pitetti \\ Universidad Nacional de la Plata, \\ Buenos Aires, Argentina \\ E-mail: diegopitetti@hotmail.com
}

Fecha de recepción: 29/10/2019

Fecha de aceptación: 04/12/2019

Palabras clave

- tipo de cambio real

- depreciación

- finanzas públicas subnacionales

\section{Resumen}

El presente trabajo estudia el efecto de las depreciaciones reales sobre el escenario fiscal subnacional en Argentina para el período 1960-2017. Se analiza no solo el efecto sobre gastos, ingresos y deuda subnacional a nivel agregado, sino que también se focaliza en la composición de estas variables. El gasto se analiza según su clasificación económica — corrientes y de capital—, los ingresos según provengan de recaudación propia 0 de transferencias de otras jurisdicciones - principalmente del Gobierno Nacional - y la deuda según el prestamista — Gobierno Nacional u organismos multinacionales-. Los resultados sugieren que ante una depreciación real tanto los gastos como los ingresos caen, experimentando estos últimos una caída de mayor magnitud que deteriora el resultado fiscal y, a su vez, los efectos son heterogéneos entre las provincias. Por otra parte, la deuda pública provincial, reacciona positivamente ante dicho shock dada la elevada proporción de deuda denominada en moneda extranjera respecto del total. 
Keywords

- real exchange rate

- depreciation

- subnational public finance

\begin{abstract}
This research work focuses on the effect of real depreciation on the subnational fiscal scenario in Argentina over the period 1960-2017. Both the impact on expenditures, incomes and subnational debts at added value and the components of each variable are analyzed. Expenditures are analyzed according to their economic classification (operating and capital); incomes are analyzed based on their origin (own revenue or transfers from other jurisdictions, mainly from the national Government); and debt is analyzed depending on the moneylender (the national Government or multinational organizations). The results show that, when there is real depreciation, both expenditures and incomes decrease. The income decrease is larger, which deteriorates the fiscal outcome; the impact of this decrease in the provinces is heterogeneous. At the same time, the public debt of each province has a positive reaction to this fall, due to the high proportion of foreign currency-denominated debt out of the total debt.
\end{abstract}

\section{Resumo}

0 presente trabalho estuda 0 efeito das depreciações reais sobre 0 cenário fiscal subnacional na Argentina para o período 1960-2017. Analisa-se não apenas 0 efeito sobre gastos, ingressos e dívida subnacional a nível agregado, mas também foca-se na composição destas variáveis. As despesas analisam-se segundo sua classificação econômica -correntes e de capital-os ingressos segundo derivem de arrecadação própria ou de transferências de outras jurisdições - principalmente do Governo Nacional e a dívida segundo o prestamista -Governo Nacional ou organismos multinacionais- Os resultados sugerem que, perante uma depreciação real, tanto os gastos quanto os ingressos caem, experimentando estes últimos uma queda de maior magnitude que deteriora 0 resultado fiscal e, ao mesmo tempo, os efeitos são heterogêneos entre as províncias. Por outro lado, a dívida pública provincial, reage positivamente perante dito choque pela elevada proporção da dívida denominada em moeda estrangeira a respeito do total.
Palavras-Chave

- tipo de câmbio real - depreciação - finanças públicas subnacionais 